Article

\title{
Novel Substituted Thiophenes and Sulf-Polyacetylene Ester from Echinops ritro L.
}

\author{
Liang-Bo Li® ${ }^{\oplus}$, Guang-Da Xiao, Wei Xiang, Xing Yang, Ke-Xin Cao and Rong-Shao Huang * \\ Department of Agronomy, Agricultural College of Guangxi University; Nanning 530004, China; \\ 1lb100@126.com (L.-B.L.); xgd0104@163.com (G.-D.X.); victorxiang@st.gxu.edu.cn (W.X.); \\ Hdyx0000@163.com (X.Y.); 18991697639@163.com (K.-X.C.) \\ * Correspondence: hrs17252@gxu.edu.cn; Tel./Fax: +86-771-323-5612 \\ Academic Editor: Francesco Epifano \\ Received: 17 November 2018; Accepted: 13 February 2019; Published: 22 February 2019

\begin{abstract}
Three new substituted bithiophenes (1-3), and one new sulf-polyacetylene ester, ritroyne A (16) were isolated from the whole plant of Echinops ritro together with twelve known substituted thiophenes. The structures were elucidated on the basis of extensive spectroscopic analysis including 1D and 2D NMR as well as MS. Furthermore, the absolute configuration of ritroyne A (16) was established by computational methods. In bioscreening experiments, four compounds $(\mathbf{2}, \mathbf{4}, \mathbf{1 2}, \mathbf{1 4})$ showed similar antibacterial activity against Staphylococcus aureus ATCC 2592 with levofloxacin $(8 \mu \mathrm{g} / \mathrm{mL})$. Five compounds $(\mathbf{2}, 4,9, \mathbf{1 2}, \mathbf{1 4})$ exhibited antibacterial activities against Escherichia coli ATCC 25922, with minimum inhibitory concentration (MIC) values of 32-64 $\mu \mathrm{g} / \mathrm{mL}$. Three compounds $(\mathbf{2}, \mathbf{4}, \mathbf{1 2})$ exhibited antifungal activities against Candida albicans ATCC 2002 with MIC values of 32-64 $\mu \mathrm{g} / \mathrm{mL}$. However, compound 16 did not exhibit antimicrobial activities against three microorganisms.
\end{abstract}

Keywords: Echinops ritro; thiophenes; sulf-polyacetylene; antimicrobial activities

\section{Introduction}

The genus Echinops (Compositae) comprises over 120 species worldwide, widely distributed in Eastern and Southern Europe, tropical and North Africa, and Asia [1]. In Chinese Pharmacopoeias, the dried root of Echinops latifolius Tausch and Echinops grijsii Hance have been used as a well-known traditional Chinese medicine "Yuzhou Loulu" to relieve heat, expel miasma, and stimulate milk secretion [2]. In China, Echinops ritro L. has only been found in Xinjiang province, and is used instead of E. grijsii in Uighur Pharmacopeia [3]. Previous phytochemical investigations of E. ritro reported the isolation of quinoline alkaloids [4], flavonoids [5], and sesquiterpenes [6], as well as fatty acids [7] and alkanes [8]. In addition, numerous investigations of the genus Echinops have resulted in the isolation of thiophenes [9]. Thiophenes from Echinops have been proven to possess several activities, such as anti-tumor [10,11], anti-virus [11,12], insecticidal [13], and anti-fungal [14].

Compared with the intensive investigations of the root of this genus, few chemical studies have been conducted on the whole plant of E. ritro in recent years [15]. As a part of our ongoing search for bioactive secondary metabolites from Uighur medicinal plants, we herein report the isolation and structure elucidation of fifteen thiophene compounds including three new ones (1-3) and one new sulf-polyacetylene ester, ritroyne A (16), from E. ritro as well as their antimicrobial activities.

\section{Results and Discussion}

The $95 \%$ ethanolic whole-plant extract of E. ritro was subjected to separation using various chromatographic techniques, such as liquid-liquid extraction, silica gel column, octadecylsilyl (ODS) 
column, Sephadex LH-20 column, and medium-pressure liquid chromatography (MPLC), to obtain three new substituted bithiophenes (1-3) and one new sulf-polyacetylene ester, ritroyne A (16), together with 12 known substituted thiophenes (4-15) (Figure 1).

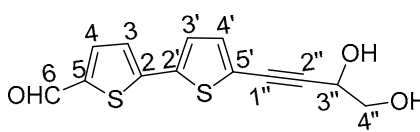

1

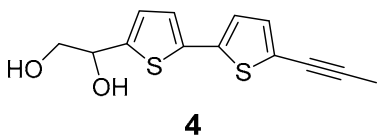

4

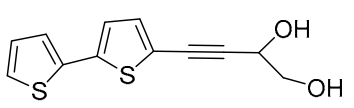

7
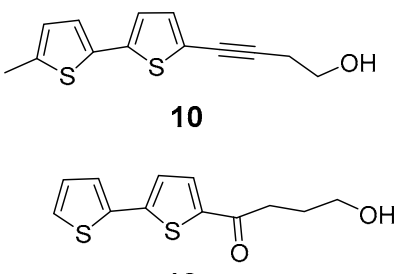

13

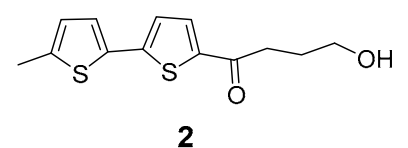

2
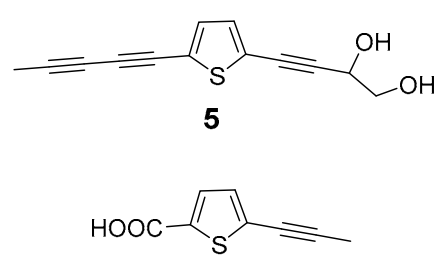

8
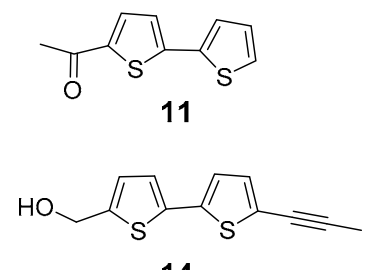

14
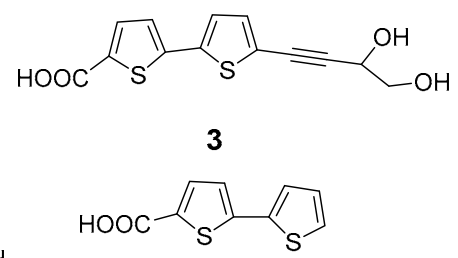

6

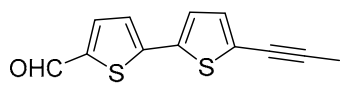

9

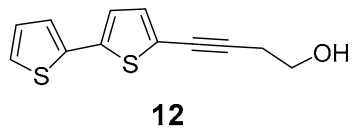

12

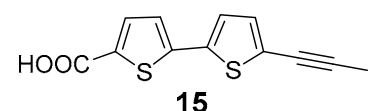

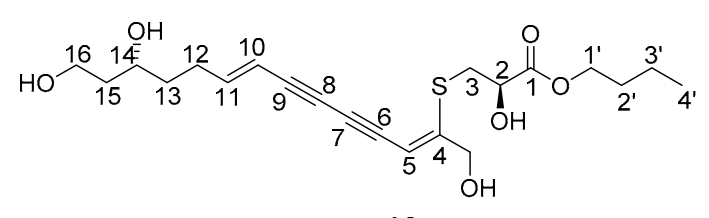

16

Figure 1. Chemical structures of compounds 1-16 from Echinops ritro L.

\subsection{Structure Elucidation of the Compounds}

Compound 1 was obtained as a primrose-yellow amorphous powder. Its high-resolution electrospray ionization (ESI) mass spectrum displayed a $[\mathrm{M}+\mathrm{H}]^{+}$ion peak at $m / z 279.0145$, indicating a molecular formula of $\mathrm{C}_{13} \mathrm{H}_{10} \mathrm{O}_{3} \mathrm{~S}_{2}$. Absorption bands at $3283 \mathrm{~cm}^{-1}$ and $2217 \mathrm{~cm}^{-1}$ in the IR spectrum were observed, suggesting the existence of hydroxyl and alkyne groups. The ${ }^{1} \mathrm{H}-\mathrm{NMR}$ spectrum data of 1 (Table 1 and Figure S7), coupled with the ${ }^{1} \mathrm{H}-{ }^{1} \mathrm{H}$ COSY spectrum (Figure S11 and Figure 2), showed two sets of low field signals, attributable to four methine protons on two thiophene rings $(\delta 7.85$ and 7.41 , each $1 \mathrm{H}, \mathrm{d}, J=4.0 \mathrm{~Hz} ; \delta 7.37$ and 7.22 , each $1 \mathrm{H}, \mathrm{d}, J=3.8 \mathrm{~Hz})$, a triplet $(\delta 4.56,1 \mathrm{H}, \mathrm{t}$, $J=6.5 \mathrm{~Hz})$ and a multiplet $(\delta 3.67,2 \mathrm{H}, \mathrm{m})$, attributable to a $\mathrm{CH}(\mathrm{OH}) \mathrm{CH}_{2} \mathrm{OH}$ moiety, and a singlet $(\delta 9.85,1 \mathrm{H})$ attributable to aldehyde group proton. The ${ }^{13} \mathrm{C}-\mathrm{NMR}$ spectrum (Table 1 and Figure S8) showed 13 carbon signals, and characteristic signals including one aldehyde carbon signal, a pair of alkyne carbons signals, eight bithiophene ring signals, and one methoxy group. Careful comparison of the NMR data of 1 with those of a known substituted thiophene compound 7 [16] revealed that the two compounds were similar, except $\mathbf{1}$ had an additional aldehyde group that was absent in $\mathbf{7}$. Analysis of correlations observed in the HMBC spectrum (Figure S10 and Figure 2) allowed the position of the aldehyde group to be elucidated. The $\mathrm{H}-4$ proton signal showed ${ }^{1} \mathrm{H}^{-13} \mathrm{C}$ long-range correlation with C-6, and the H-6 proton signal showed correlations with C-5, indicating that the additional aldehyde group was assignable to $C-5$. From the above data, the planar structure of 1 was elucidated as 5'-(3,4-dihydroxybut-1-yn-1-yl)-[2,2'-bithiophene]-5-carbaldehyde. 
Table 1. ${ }^{1} \mathrm{H}-\mathrm{NMR}(500 \mathrm{MHz})$ and ${ }^{13} \mathrm{C}-\mathrm{NMR}(125 \mathrm{MHz})$ data of $\mathbf{1 - 3}\left({ }^{\mathrm{a}}\right.$ is recorded in methanol- $d_{4} ;{ }^{\mathrm{b}}$ is recorded in $\mathrm{CDCl}_{3}$ ) ( $\delta$ in ppm, $J$ in $\mathrm{Hz}$ ).

\begin{tabular}{|c|c|c|c|c|c|c|}
\hline & \multicolumn{2}{|c|}{$1^{a}$} & \multicolumn{2}{|c|}{$2^{b}$} & \multicolumn{2}{|c|}{$3^{a}$} \\
\hline & $\delta_{C}$ & $\delta_{H}$ mult $(J)$ & $\delta_{C}$ & $\delta_{H}$ mult $(J)$ & $\delta_{C}$ & $\delta_{H}$ mult $(J)$ \\
\hline 2 & 146.9 & & $134.0 \mathrm{~s}$ & & $138.6 \mathrm{~s}$ & \\
\hline 3 & 126.4 & $7.41 \mathrm{~d}(4.0)$ & $125.7 \mathrm{~d}$ & $7.12 \mathrm{~d}(3.6)$ & $123.7 \mathrm{~d}$ & $7.16-7.19 \mathrm{~m}$ \\
\hline 4 & 139.6 & $7.85 \mathrm{~d}(4.0)$ & $126.5 \mathrm{~d}$ & $6.71 \mathrm{~d}(3.6)$ & $133.4 \mathrm{~d}$ & $7.16-7.19 \mathrm{~m}$ \\
\hline 5 & 143.6 & & $141.3 \mathrm{~s}$ & & $135.5 \mathrm{~s}$ & \\
\hline 6 & 184.8 & $9.85 \mathrm{~s}$ & $15.4 \mathrm{q}$ & $2.50 \mathrm{~s}$ & $164.3 \mathrm{~s}$ & \\
\hline $2^{\prime}$ & 138.3 & & $146.3 \mathrm{~s}$ & & $128.5 .3 \mathrm{~s}$ & \\
\hline $3^{\prime}$ & 127.3 & $7.37 \mathrm{~d}(3.8)$ & $123.4 \mathrm{~d}$ & $7.09 \mathrm{~d}(4.0)$ & $124.6 \mathrm{~d}$ & $7.16-7.19 \mathrm{~m}$ \\
\hline $4^{\prime}$ & 134.7 & $7.22 \mathrm{~d}(3.8)$ & $133.0 \mathrm{~d}$ & $7.61 \mathrm{~d}(4.0)$ & & $7.16-7.19 \mathrm{~m}$ \\
\hline $5^{\prime}$ & 125.4 & & $141.7 \mathrm{~s}$ & & $120.4 \mathrm{~s}$ & \\
\hline $1^{\prime \prime}$ & 78.2 & & $193.0 \mathrm{~s}$ & & $76.7 \mathrm{~s}$ & \\
\hline $2^{\prime \prime}$ & 95.8 & & $35.5 \mathrm{t}$ & $3.04 \mathrm{t}(7.0)$ & $96.1 \mathrm{~s}$ & \\
\hline $3^{\prime \prime}$ & 64.7 & $4.56 \mathrm{t}(6.5)$ & $27.2 \mathrm{t}$ & $1.98-2.05 \mathrm{~m}$ & $63.1 \mathrm{~d}$ & $4.40 \mathrm{t}(6.0)$ \\
\hline $4^{\prime \prime}$ & 67.0 & $3.67 \mathrm{~m}$ & $62.3 \mathrm{t}$ & $3.75 \mathrm{t}(6.0)$ & $65.5 \mathrm{t}$ & $3.47 \mathrm{~d}(6.0)$ \\
\hline
\end{tabular}

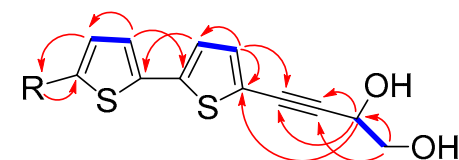

1, $\mathrm{R}=\mathrm{CHO}, 3, \mathrm{R}=\mathrm{CO}_{2} \mathrm{H}$

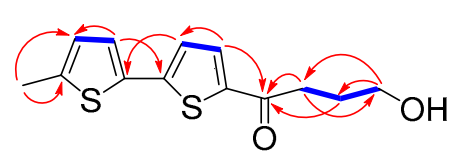

2

Figure 2. ${ }^{1} \mathrm{H},{ }^{1} \mathrm{H}-\mathrm{COSY}(-)$ and key correlations in $\mathrm{HMBC}$ spectra $(\mathrm{H} \longrightarrow \mathrm{C})$ of compounds 1-3.

Compound 2 was obtained as a yellowish-white amorphous powder. Accurate mass measurement of an $[\mathrm{M}+\mathrm{H}]^{+}$ion peak at $m / z 267.0506$ in HR-ESI-MS allowed a molecular formula of $\mathrm{C}_{13} \mathrm{H}_{14} \mathrm{O}_{2} \mathrm{~S}_{2}$ to be assigned to compound 2. IR absorption bands at $3277 \mathrm{~cm}^{-1}$ for the hydroxyl group and at $1651 \mathrm{~cm}^{-1}$ for the carbonyl group were observed. The ${ }^{1} \mathrm{H}-\mathrm{NMR}$ spectrum of compound 2 (Table 1 ) displayed two pairs of proton signals $(\delta 7.12$ and 6.71 , each $1 \mathrm{H}, \mathrm{d}, J=3.6 \mathrm{~Hz} ; 7.61$ and 7.09 , each $1 \mathrm{H}, \mathrm{d}$, $J=4.0 \mathrm{~Hz}$ ), which indicated the presence of 5,5'-substituted 2,2'-bithiophene moiety. The ${ }^{1} \mathrm{H}-\mathrm{NMR}$ spectrum of compound 2 also exhibited signals of one methyl protons at $\delta_{\mathrm{H}} 2.50(\mathrm{~s}, 3 \mathrm{H})$, one oxygenated methylene protons at $\delta_{\mathrm{H}} 3.75(\mathrm{t}, 2 \mathrm{H}, J=6.0 \mathrm{~Hz})$, and two methylene protons at $\delta_{\mathrm{H}} 3.04(\mathrm{t}, 2 \mathrm{H}, J=7.0 \mathrm{~Hz})$ and 1.98-2.05 (m, 2H). The ${ }^{13} \mathrm{C}-\mathrm{NMR}$ and DEPT spectra of 2 (Table 1) showed 13 carbon signals, attributed to eight bithiophene carbon signals, three methylene signals, one methyl signal, and one carbonyl signal. Careful comparison of the NMR data of 2 with those of compound 13 [17] revealed that compound 2 had one more methyl group than 13. Analysis of the ${ }^{1} \mathrm{H}-{ }^{1} \mathrm{H}$ COSY and HSQC spectral data of 2 led to the identification of two partial structures: $\left(-\mathrm{CH}_{2}-\mathrm{CH}_{2}-\mathrm{CH}_{2}-\mathrm{OH}\right)$ and $-\mathrm{CH}_{3}$. Based on HMBC correlations (Figure S19 and Figure 2) from H-6 to C-4 and C-5, and H- $4^{\prime}$ to C- $1^{\prime \prime}$, the methyl and the 4-hydroxybutyryl groups were located at positions C-5 and C-5', respectively. Thus, on the basis of the above conclusions, the structure of compound 2 was determined to be 4-hydroxy-1-(5'-methyl-[2,2'-bithiophen]-5-yl)butan-1-one.

Compound 3 was obtained as primrose-yellow needle crystals, possessing the molecular formula $\mathrm{C}_{13} \mathrm{H}_{10} \mathrm{O}_{4} \mathrm{~S}_{2}$ by HR-ESI-MS $\left(\mathrm{m} / z 292.9958[\mathrm{M}-\mathrm{H}]^{+}\right)$. The IR spectrum indicated the presence of hydroxyl group $\left(3426 \mathrm{~cm}^{-1}\right)$, carbonyl group $\left(1630 \mathrm{~cm}^{-1}\right)$, and alkyne group $\left(2310 \mathrm{~cm}^{-1}\right)$. The ${ }^{1} \mathrm{H}-\mathrm{NMR}$ spectrum of compound 3 (Table 1) showed one oxymethine proton at $\delta_{\mathrm{H}} 4.40(\mathrm{t}, 1 \mathrm{H}, J=6.0 \mathrm{~Hz})$ and one oxymethylene proton at $\delta_{\mathrm{H}} 3.47(\mathrm{~d}, 2 \mathrm{H}, \mathrm{J}=6.0 \mathrm{~Hz})$, attributable to a $\mathrm{CH}(\mathrm{OH}) \mathrm{CH}_{2} \mathrm{OH}$ moiety, and four overlapped aromatic protons at $\delta_{\mathrm{H}} 7.16-7.19(\mathrm{~m}, 4 \mathrm{H})$ suggested that 3 was similar to 1 . The ${ }^{13} \mathrm{C}-\mathrm{NMR}$ and DEPT spectra (Table 1) were in agreement with the above observations. The only difference between these two compounds was that the aldehyde group in $\mathbf{1}$ could be oxidized to a carboxylic acid in 3 . This was confirmed by the signal of C-6 at $\delta_{C} 184.8$ in 1 shifted to up-field at $\delta_{C} 164.3$ in 3 . Normally, aldehydes can be converted to acids by strong oxidants. It was difficult to convert compound 1 into 3 
under relatively mild conditions during the separation and extraction process. Therefore, compound 3 may be a natural product existing in E. ritro. Thus, the planar structure of compound $\mathbf{3}$ was elucidated as 5'-(3,4-dihydroxybut-1-yn-1-yl)-[2,2'-bithiophene]-5-carboxylic acid.

Ritroyne A (16) was obtained as a yellowish powder. The IR spectrum of compound 1 indicated the presence of a hydroxy group $\left(3425 \mathrm{~cm}^{-1}\right)$, a carbonyl group $\left(1734 \mathrm{~cm}^{-1}\right)$, two $C=C$ bonds $(2957$, $\left.2932 \mathrm{~cm}^{-1}\right)$, and two $\mathrm{C} \equiv \mathrm{C}$ bonds $\left(2198,2126 \mathrm{~cm}^{-1}\right)$. Its molecular formula $\mathrm{C}_{21} \mathrm{H}_{30} \mathrm{O}_{6} \mathrm{~S}$ was determined by HR-ESI-MS experiments (calc. for [M + Na] ${ }^{+}: 433.1660$; found: 433.1664), in combination with ${ }^{1} \mathrm{H}-\mathrm{NMR}$ and ${ }^{13} \mathrm{C}-\mathrm{NMR}$ spectral data (Table 2) indicating seven degrees of unsaturation. Analysis of the ${ }^{1} \mathrm{H}-\mathrm{NMR}$ data and HSQC spectra revealed the occurrence of a pair olefinic protons at $\delta_{\mathrm{H}} 6.38(\mathrm{dt}, 1 \mathrm{H}, J=16.0$, $7.2 \mathrm{~Hz})$ and $5.70(\mathrm{~d}, 1 \mathrm{H}, J=16.0 \mathrm{~Hz})$ connected with a methylene, together with an isolated olefinic proton at $\delta_{\mathrm{H}} 5.91(\mathrm{~s}, 1 \mathrm{H})$, six methylenes and three oxygenated methylene protons at $\delta_{\mathrm{H}} 4.34(\mathrm{~d}, 2 \mathrm{H}$, $J=6.0 \mathrm{~Hz}), 4.12-4.14(\mathrm{~m}, 2 \mathrm{H})$ and $3.69(\mathrm{t}, 2 \mathrm{H}, J=10.5 \mathrm{~Hz})$, two oxygenated methine protons at $\delta_{\mathrm{H}} 4.36-4.38$ $(\mathrm{m}, 1 \mathrm{H})$ and $3.71-3.74(\mathrm{~m}, 1 \mathrm{H})$, and one methyl proton at $\delta_{\mathrm{H}} 0.90(\mathrm{t}, 3 \mathrm{H}, J=7.6 \mathrm{~Hz})$. The ${ }^{13} \mathrm{C}-\mathrm{NMR}$ and DEPT spectra showed twenty-one carbon signals, and characteristic signals included four alkyne signals, two oxygenated methylene signals, three oxygenated methylene signals, six methylene signals, one methyl signal, one carbonyl group, and four olefinic signals. The ${ }^{1} \mathrm{H}-{ }^{1} \mathrm{H}$ COSY spectrum (Figure S34 and Figure 3) revealed the connectivity of three structural fragments: C-10-C-11-C-12-C-13-C-14-C-15-C-16, C-2-C-3, and $C-1^{\prime}-C-2^{\prime}-C-3^{\prime}-C-4^{\prime}$. The connection of $C-5$ to $C-10$ via the conjugated diynes was deduced from the observed HMBC correlations (Figure S34 and Figure 3) H-12/C-9 and C-10; H-11/C-8 and C-9; H-10/C-6, C-7 and C-8; H-5/C-6 and C-7; and H-17/C-5, C-6, and C-7. Note that HMBC correlations over three bonds were detected, due to the existence of a conjugated system. A similar phenomenon was also observed in the structure of callyberyne $\mathrm{A}, \mathrm{a} \mathrm{C}_{21}$ polyyne from a marine sponge [18]. The position of the S-bond was deduced from the lower field chemical shift of $C-3\left[\delta_{C} 34.7(\mathrm{t})\right]$ and $C-4\left[\delta_{C} 155.8(\mathrm{~s})\right]$ compared with the standard value. This was further confirmed by the HMBC correlations $\mathrm{H}-3 / \mathrm{C}-4$, as well as three bonds correlations H-4/C-3, H-17/C-3, and H-3/C-17 were not detected. The connection of C-2 to C-1' via the ester group was confirmed by the HMBC correlations H-1 ${ }^{\prime} / \mathrm{C}-1, \mathrm{H}-3 / \mathrm{C}-1$ and $2-\mathrm{OH} / \mathrm{C}-1$. The $\Delta^{(10,11)}$ was assigned as trans from the large vicinal coupling constants [ $\left.{ }^{3} \mathrm{~J}(\mathrm{H}-10,11)=16.0 \mathrm{~Hz}\right]$, and the ROESY (Figure S35 and Figure 3) correlation H-12/H-10. The ROESY correlation H-17/H-5 confirmed the $\Delta^{(4,5)}$ was cis. Finally, absolute configuration of $\mathbf{1 6}$ was determined by our previously constructed matrix method [19,20]. The computed det $\left(\mathrm{D}_{1}\right)$ for C-2 with $(R)$ configuration is +8.31 and $\operatorname{det}\left(\mathrm{D}_{2}\right)$ for $(R)-\mathrm{C}-14$ is -7.49 . Four cases, $(2 R, 14 R)-\mathbf{1 6},(2 R, 14 S)-\mathbf{1 6},(2 S, 14 R)-\mathbf{1 6}$, and $(2 S, 14 S)-\mathbf{1 6}$ were investigated, sum of $\operatorname{det}\left(\mathrm{D}_{\mathrm{i}}\right)(\mathrm{i}=1$ and 2$)$ values for the four cases were computed to be $+6.45,+1.39,-1.39$, and -6.45 , respectively. The recorded optical rotation value $[\alpha]_{D}$ was +32.1 , thus, the $k_{0}$ values $\left([\alpha]_{D} / \operatorname{det}(\mathrm{D})\right)$ for the four cases were 5.0, 23.1, -23.1 , and -5.0 , respectively. Due to the requirement that $k_{0}$ values should be positive for tertiary alcohols or amines, two cases with negative $k_{0}$ values $((2 S, 14 R)-\mathbf{1 6}$ and $(2 S, 14 S))-\mathbf{1 6}$ could be excluded. Considering that the $k_{0}$ values for the tertiary alcohols are generally from $0.5-6.0$ in different chiral alcohols, only the case where $k_{0}$ is 5.0 matched all conditions. The predicted absolute configuration for $\mathbf{1 6}$ is $(2 R, 14 R)$.

The twelve known substituted thiophene compounds isolated from E. ritro L. were identified as arctinol b (4) [21], 4-(5-(penta-1,3-diyn-1-yl)thiophen-2-yl)but-3-yne-1,2-diol (5) [22], [2,2'-bithiophene]5-carboxylic acid (6) [23], 4-([2,2'-bithiophen]-5-yl) but-3-yne-1,2-diol (7) [24], junipic acid (8) [23], arctinal (9) [24], 4-(5'-methyl-[2,2'-bithiophen]-5-yl)but-3-yn-1-ol (10) [25], ethanone (11) [26], 4-([2,2' bithiophen]-5-yl)but-3-yn-1-ol (12) [17], 1-([2,2'-bithiophen]-5-yl)-4 -hydroxybutan-1-one (13) [17], arctinol A (14) [25], and arctic acid (15) [27], respectively, by comparison of their spectral data $\left({ }^{1} \mathrm{H}\right.$, ${ }^{13} \mathrm{C}-\mathrm{NMR}$ and MS) with those reported in the literature. 
Table 2. ${ }^{1} \mathrm{H}-(400 \mathrm{MHz})$ and ${ }^{13} \mathrm{C}-\mathrm{NMR}(100 \mathrm{MHz})$ data of 16 in acetone- $d_{6}(\delta$ in ppm, $J$ in $\mathrm{Hz})$.

\begin{tabular}{|c|c|c|c|c|c|}
\hline & 16 & \multirow{2}{*}{$\delta_{C}$} & & \multirow{2}{*}{$\delta_{H}$} & \multirow{2}{*}{$\delta_{C}$} \\
\hline & $\delta_{H}$ & & & & \\
\hline 1 & & 179.2 & 11 & $6.38 \mathrm{dt}(16,7.2)$ & 149.8 \\
\hline 2 & $4.36-4.38 \mathrm{~m}$ & 71.5 & 12 & $2.26-2.29 \mathrm{~m}$ & 29.6 \\
\hline 3 & $\begin{array}{l}3.39 \mathrm{dd}(11.5,4.4) \\
3.25 \mathrm{dd}(11.5,4.4)\end{array}$ & 34.7 & 13 & $1.50-1.54 \mathrm{~m}$ & 37.3 \\
\hline 4 & & 155.8 & 14 & $3.71-3.74 \mathrm{~m}$ & 69.5 \\
\hline 5 & $5.91 \mathrm{~s}$ & 103.7 & 15 & $1.59-1.61 \mathrm{~m}$ & 40.4 \\
\hline 6 & & 81.8 & 16 & $3.69 \mathrm{t}(10.5)$ & 60.5 \\
\hline 7 & & 78.4 & 17 & $4.34 \mathrm{~d}(6.0)$ & 64.6 \\
\hline 8 & & 73.2 & $1^{\prime}$ & $4.12-4.14 \mathrm{~m}$ & 65.5 \\
\hline 9 & & 83.5 & $2^{\prime}$ & $1.62-1.64 \mathrm{~m}$ & 31.3 \\
\hline 10 & $5.69 \mathrm{~d}(16)$ & 109.2 & $3^{\prime}$ & $1.36-1.40 \mathrm{~m}$ & 19.7 \\
\hline $2-\mathrm{OH}$ & $4.77 \mathrm{~d}(6.0)$ & & $4^{\prime}$ & $0.90 \mathrm{t}(7.6)$ & 13.9 \\
\hline $17-\mathrm{OH}$ & $4.59 \mathrm{t}(6.0)$ & & $14-\mathrm{OH}$ & $3.85 \mathrm{~d}(4.8)$ & \\
\hline
\end{tabular}

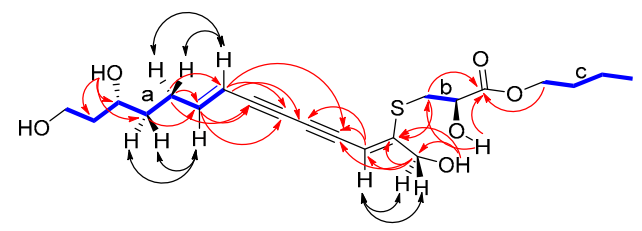

Figure 3. ${ }^{1} \mathrm{H},{ }^{1} \mathrm{H}-\mathrm{COSY}(\longrightarrow)$, key $\operatorname{HMBC}(\mathrm{H} \longrightarrow \mathrm{C})$, and key ROESY $(\leftrightarrow)$ ) correlations of 16.

\subsection{In Vitro Antimicrobial Activity}

All the sulfur-containing compounds isolated from E. ritro were tested for their potential antimicrobial effects on S. aureus ATCC 2592, E. coli ATCC 25922, and C. albicans ATCC2002. The antimicrobial abilities of these compounds isolated from E. ritro are shown in Table 3. Among the 16 compounds tested, $\mathbf{2}, \mathbf{4}, \mathbf{9}, \mathbf{1 2}$, and $\mathbf{1 4}$ showed antibacterial activities against $S$. aureus ATCC 2592 and E. coli ATCC 25922. Compounds 2, 4, and $\mathbf{1 2}$ exhibited antifungal activities against $C$. albicans ATCC 2002. Thiophenes from Echinops have been reported to possess many biological activities, including insecticidal [28] and fungicidal [29]; however, antibacterial activities of thiophenes have rarely been reported. Compounds $\mathbf{5}$ and $\mathbf{1 2}$ which were isolated from E. ritro have been reported to exhibit significant antifungal activity against Colletotrichum species and Fusarium [14], but 5 showed no antimicrobial activity according to our research. Thus, the findings obtained in this study are consistent with the previous antimicrobial studies revealing the potent antibacterial activities of thiophene-type compounds, which deserve further studies on the way to discover new antibacterial agents.

Table 3. Antimicrobial activities (MIC) of the compounds (1-4, 9, 12, 14, 16).

\begin{tabular}{cccc}
\hline \multicolumn{4}{c}{ MIC $(\mu \mathrm{g} / \mathrm{mL})$} \\
\hline Compounds & S. aureus ATCC 2592 & E. coli ATCC 25922 & C. albicans ATCC 2002 \\
\hline $\mathbf{1}$ & 128 & 256 & 256 \\
$\mathbf{2}$ & 8 & 32 & 32 \\
$\mathbf{3}$ & 256 & $>512$ & $>512$ \\
$\mathbf{4}$ & 8 & 64 & 64 \\
$\mathbf{9}$ & 32 & 64 & $>512$ \\
$\mathbf{1 2}$ & 8 & 64 & 64 \\
$\mathbf{1 4}$ & 8 & 64 & $>512$ \\
$\mathbf{1 6}$ & $>512$ & $>512$ & $>512$ \\
levofloxacin & 8 & 16 & 64 \\
\hline
\end{tabular}




\section{Experimental Section}

\subsection{General Procedures}

Infrared radiation (IR) spectra were measured on a Bio-Rad FTS-135 FTIR spectrometer (Hercules, CA, USA) on KBr pellets. Optical rotations were measured using a JASCO P-1020 automatic digital polarimeter (Easton, PA, USA). NMR spectra were recorded on a Bruker AM-400 and DRX-500 spectrometer (Karlsruhe, Germany) using standard Bruker pulse programs. Chemical shifts were shown as $\delta$-values with reference to tetramethylsilane (TMS) as an internal standard. The ESI-MS and HR-ESI-MS were recorded on an API Qstar Pulsa LC/TOF spectrometer (Foster City, CA, USA). Sephadex LH-20 (Pharmacia Fine Chemical Co. Ltd. Uppsala, Sweden), silica gel (Qingdao Ocean Chemical Co., Ltd., Qingdao, China), and ODS (40-63 m, Merck, Darmstadt, Germany) were used for column chromatography (CC). Thin-layer chromatography (TLC) was carried out on preparative Silica gel 60 F254 and RP-18 F254 plates (Merck, Darmstadt, Germany), and spots were visualized by spraying the plates with $10 \% \mathrm{H}_{2} \mathrm{SO}_{4}$ / ethanol, and heating them at $105^{\circ} \mathrm{C}$. A Buchi Sepacore System (Fällanden, Switzerland) was used for medium-pressure liquid chromatographic (MPLC) separations.

\subsection{Plant Material}

Air-dried whole plants of Echinops ritro L. were obtained from Qinghe County, Xinjiang Province, China, in August 2007, and were identified by Prof. Rongshao Huang of Agricultural College of Guangxi University in Nanning. A voucher specimen (No. 20070810) was maintained in the lab of Agricultural College of Guangxi University in Nanning (530004), China.

\subsection{Extraction and Isolation}

The air-dried whole plants of E. ritro $(30 \mathrm{~kg})$ were extracted with $95 \% \mathrm{EtOH}(150 \mathrm{~L} \times 3)$ and refluxed. Evaporation of the organic solvent under reduced pressure at $55^{\circ} \mathrm{C}$ yielded a crude extract (5500.0 g). The concentrated brown syrup was resuspended in water and partitioned with ethyl acetate $(15.0 \mathrm{~L} \times 3)$ and water-saturated $\mathrm{n}$-butanol $(10.0 \mathrm{~L} \times 3)$ gradually to afford $500.0 \mathrm{~g}$ and $450.0 \mathrm{~g}$ of dried organic extracts, respectively.

The ethyl acetate fraction (500.0 g) was absorbed on $750 \mathrm{~g}$ silica gel and fractionated over a silica gel $(4 \mathrm{~kg}, 200-300$ mesh, $10 \times 150 \mathrm{~cm})$ column by eluting gradually with $\mathrm{CHCl}_{3}: \mathrm{MeOH}(100: 1(30 \mathrm{~L})$, 50:1 (30 L), 20:1 (30 L), 10:1 (20 L), 5:1 (20 L), 2:1 (20 L)) to yield six main fractions, namely A-F. Fraction A (13.0 g) was subjected to medium-pressure liquid chromatography $\left(\mathrm{SiO}_{2}, 1300 \mathrm{~g}\right)$ eluting with stepwise petroleum ether-acetone gradient ( $0 \%$ to $50 \%$ acetone) and purified by Sephadex LH-20 (20 g) CC (MeOH: $\left.\mathrm{CHCl}_{3}=1: 1,200 \mathrm{~mL}\right)$ to afford 1 (6 mg), 4 (120 mg), and 9 (160 mg). In a similar way, compounds 5 (14 mg) and 7 (23 mg) were obtained from fraction B (30 g). Fraction E (55.0 g) was subjected to preparative medium-pressure liquid chromatography (C18-MPLC, $1600 \mathrm{~g}$ ) eluting with stepwise $\mathrm{H}_{2} \mathrm{O}-\mathrm{MeOH}$ gradient $(10 \%$ to $90 \% \mathrm{MeOH})$ to obtain fractions $\mathrm{E}_{1-3}$. Purification of $\mathrm{E}_{2}(1800 \mathrm{mg})$ by medium-pressure liquid chromatography $\left(\mathrm{SiO}_{2}, 200 \mathrm{~g}\right)$ eluting with stepwise petroleum ether-acetone gradient (5\% to 60\% acetone) yielded compounds 8 (16 mg), 11 (11 mg), 12 (25 mg), and 13 (21 mg), as well as an additional fraction containing impure 2 . Compound $2(8 \mathrm{mg})$ was also purified from the latter fraction $(20 \mathrm{mg})$ by Sephadex LH-20 $(20 \mathrm{~g}) \mathrm{CC}(\mathrm{MeOH}, 200 \mathrm{~mL})$. Fraction $\mathrm{E}_{3}(2.0 \mathrm{~g})$ was subjected to medium-pressure liquid chromatography $\left(\mathrm{SiO}_{2}, 240 \mathrm{~g}\right)$ eluting with stepwise petroleum ether-acetone gradient ( $0 \%$ to $40 \%$ acetone) to give compounds 6 (51 mg), $14(23 \mathrm{mg})$, and 15 (10 mg). Fraction F (3.5 g) was fractionated over a Sephadex LH $(250 \mathrm{~g})$ column $(\mathrm{MeOH}, 1500 \mathrm{~mL})$ to obtain three main subfractions, fractions $\mathrm{F}_{1-3}$. Rechromatography of fraction $\mathrm{F}_{2}(500 \mathrm{mg})$ by $\mathrm{MPLC}\left(\mathrm{SiO}_{2}, 60 \mathrm{~g}\right)$ eluting with stepwise petroleum ether-acetone gradient (10\% to 60\% acetone) afforded compounds 3 (60 mg), 10 (16 mg), and 16 (40 mg). The structures of new compounds 1-3 and $\mathbf{1 6}$ are shown in Figure 1. 


\subsection{Compound Characterization Data}

5'-(3,4-Dihydroxybut-1-yn-1-yl)-[2,2'-bithiophene]-5-carbaldehyde (1). Primrose-yellow amorphous powder; IR $\left(\mathrm{KBr}, \mathrm{cm}^{-1}\right) v_{\max } 3282(\mathrm{OH}), 3087,2963,2927,2217,1650,1455,1436,1233,1086,1057$; ${ }^{1} \mathrm{H}-\mathrm{NMR}\left(500 \mathrm{MHz}\right.$, methanol- $\left.d_{4}\right)$ and ${ }^{13} \mathrm{C}-\mathrm{NMR}\left(125 \mathrm{MHz}\right.$, methanol- $\left.d_{4}\right)$ spectroscopic data, see Table 1 ; EI-MS ( $m / z): 278$ [M] $^{+}, 260\left[\mathrm{M}-\mathrm{H}_{2} \mathrm{O}\right]^{-}, 247,231,218,190,171,158,145,95,69$; HR-ESI-MS $(\mathrm{m} / z)$ : $279.0145[\mathrm{M}+\mathrm{H}]^{+}$, Calc. for $\left[\mathrm{C}_{13} \mathrm{H}_{11} \mathrm{O}_{3} \mathrm{~S}_{2}+\mathrm{H}\right]^{+} 279.0149$.

4-Hydroxy-1-(5'-methyl-[2,2'-bithiophen]-5-yl)butan-1-one (2). Yellowish-white amorphous powder; IR (KBr, cm $\left.{ }^{-1}\right) v_{\max } 3277(\mathrm{OH}), 3065,2953,2863,1651,1509,1453,1207,1052,1014,807$; ${ }^{1} \mathrm{H}-\mathrm{NMR}\left(500 \mathrm{MHz}, \mathrm{CDCl}_{3}\right)$ and ${ }^{13} \mathrm{C}-\mathrm{NMR}\left(125 \mathrm{MHz}, \mathrm{CDCl}_{3}\right)$ spectroscopic data, see Table 1; EI-MS $(m / z): 266[\mathrm{M}]^{+}, 248\left[\mathrm{M}-\mathrm{H}_{2} \mathrm{O}^{-}, 222,207,179,149,135,91,69\right.$; HR-ESI-MS $(m / z): 267.0506[\mathrm{M}+\mathrm{H}]^{+}$, calcd for $\left[\mathrm{C}_{13} \mathrm{H}_{14} \mathrm{O}_{2} \mathrm{~S}_{2}+\mathrm{H}\right]^{+} 267.0513$.

5'-(3,4-Dihydroxybut-1-yn-1-yl)-[2,2'-bithiophene]-5-carboxylic acid (3). Primrose-yellow needles crystals, mp.: 216-220 ${ }^{\circ} \mathrm{C}$; IR (KBr, cm $\left.{ }^{-1}\right) v_{\max } 3426(\mathrm{OH}), 2311,1630,1552,1434,1379,1320,1149$, 1105, 766; ${ }^{1} \mathrm{H}-\mathrm{NMR}\left(500 \mathrm{MHz}, \mathrm{CD}_{3} \mathrm{OD}\right)$ and ${ }^{13} \mathrm{C}-\mathrm{NMR}\left(125 \mathrm{MHz}, \mathrm{CD}_{3} \mathrm{OD}\right)$ spectroscopic data, see Table 1; ESI-MS $(m / z): 293\left[\mathrm{M}-\mathrm{H}^{+}, 277,249\right.$; HR-ESI-MS $(m / z): 292.9958[\mathrm{M}-\mathrm{H}]^{+}$, calcd for $\left[\mathrm{C}_{13} \mathrm{H}_{9} \mathrm{O}_{4} \mathrm{~S}_{2}-\mathrm{H}\right]^{+} 292.9942$.

Ritroyne A (16). yellow solid; [ $\alpha=+32.1$ (c 0.29 , methanol); IR $\left(\mathrm{KBr}, \mathrm{cm}^{-1}\right) v_{\max } 3452(\mathrm{OH}), 2957$, 2932, 2872, 2198, 2126, 1734, 1627, 1457,$1093 ;{ }^{1} \mathrm{H}-\mathrm{NMR}$ (400 MHz, acetone- $\left.d_{6}\right)$ and ${ }^{13} \mathrm{C}-\mathrm{NMR}(100 \mathrm{MHz}$, acetone- $d_{6}$ ) spectroscopic data, see Table 2; EI-MS $(m / z): 410,392,365,347,335,322,310,294,219,128$, 115; HR-ESI-MS $(m / z): 433.1664[\mathrm{M}+\mathrm{Na}]^{+}$, calcd for $\left[\mathrm{C}_{21} \mathrm{H}_{30} \mathrm{O}_{6} \mathrm{~S}+\mathrm{Na}\right]^{+} 433.1660$.

\subsection{Assay for Antimicrobial Activity}

The assays were performed in a similar manner as previously reported [30] using S. aureus ATCC2592, E. coli ATCC25922, and C. albicans ATCC2002. EBS medium [31] for bacteria and MYC-medium (1.0\% phytone peptone; $1.0 \%$ glucose; $50 \mathrm{mM}$ HEPES (11.9 g/L) pH 7) for fungi was used, respectively. Briefly, $100 \mu \mathrm{L}$ of bacteria suspensions were seeded into each well of 96-well cell culture plates containing $10^{6} \mathrm{CFU} / \mathrm{mL}$, exposed to the test compounds and positive control (levofloxacin) at concentrations of $516,256,128,64,32,16,8,4,2,1 \mu \mathrm{g} / \mathrm{mL}$ at $37^{\circ} \mathrm{C}$ for $24 \mathrm{~h}$. All experiments were repeated in triplicate and average MICs are reported in Table 3.

\section{Conclusions}

Three new substituted bithiophenes (1-3), and one new sulf-polyacetylene ester, ritroyne A (16), together with twelve known substituted thiophenes (4-15), were isolated from the $95 \%$ ethanolic extract of the whole plant of E. ritro. The polyacetylenes are commonly considered as precursors of thiophenes occurring in the Compositae, but sulf-polyacetylenes were rarely reported from previous phytochemical investigations [32]. To the best of our knowledge, this is also the first report on the isolation of sulf-polyacetylene fromthe Echinops genus. In addition to the phytochemical work, the in vitro biological activities of isolates were evaluated against three microorganisms (S. aureus, E. coli, and C. albicans) using a microdilution method. Compounds 2, 4, 9, 12, and 14 exhibited antibacterial activities against S. aureus ATCC 2592 and E. coli ATCC 25922. Compounds 2, 4, and 12 exhibited antifungal activities against C. albicans ATCC 2002.

Supplementary Materials: The supplementary materials are available online.

Author Contributions: R.-S.H. conceived and designed the experiments; G.-D.X. and K.-X.C. performed the experiments; L.-B.L., W.X., and X.Y. analyzed the data; L.-B.L. wrote the paper. All of the authors read and approved the final manuscript.

Funding: This research was funded by the Natural Science Foundation of Guangxi, China (2016GXNSFAA380220).

Acknowledgments: The authors deeply appreciated Huajie Zhu for chemical calculation (Hebei University, Baoding city, Hebei province, China). We are grateful to the members of the analytical group in the Laboratory of Phytochemistry, Kunming Institute of Botany, for spectral measurements. 
Conflicts of Interest: The authors declare no conflicts of interest.

\section{References}

1. Editorial Committee of Flora of China. Flora of China; Scientific Press: Beijing, China, 1987; pp. 1-3.

2. Chinese Pharmacopoeia Commission. Chinese Pharmacopoeia; China Medical Science Press: Beijing, China, 2015.

3. Editorial Committee of Flora of medicinal plants in Xinjiang. Flora of medicinal plants in Xinjiang; Xinjiang People's Press: Urumqi, China, 1984; pp. 176-177.

4. Frolova, V.I.; Ban'kovskii, A.I.; Zheleznova, E.S. Chemical study of the alkaloids of Echinops ritro. Med. Promst. SSSR. 1957, 11, 20-24.

5. Chevrier, M. The flavonoids of Echinops ritro. Fitoterapia. 1976, 47, 115-117.

6. Ulubelen, A.; Kurucu, S. Sesquiterpene acids from Echinops ritro. Fitoterapia 1991, 62, 280.

7. Chevrier, M.; Abdel Gawad, M.; Raynaud, J. Unsaponifiable, fatty acids of Echinops ritro. Pharmazie 1975, 30, 389-390. [PubMed]

8. Chevrier, M.; Abdel Gawad, M.M. Alkanes from Echinops ritro L. (Compositae). Bull. Trav. Soc. Pharm. Lyon. 1974, 18, 58-65.

9. Shukla, Y.N. Chemical, botanical and pharmacological studies on the genus Echinops: A review. J. Med. Aromat. Plant Sci. 2003, 25, 720-732.

10. Lambert, J.D.; Campbell, G.; Arnason, J.; Majak, W. Herbicidal properties of alpha-terthienyl, a naturally occurring phototoxin. Can. J. Plant Sci. 1991, 71, 215-218. [CrossRef]

11. Marles, R.J.; Hudson, J.B.; Graham, E.A.; Arnason, J.T. Structure-activity studies of photoactivated antiviral and cytotoxic tricyclic thiophenes. Photochem. Photobiol. 1992, 56, 479-487. [CrossRef] [PubMed]

12. Hudson, J.B.; Harris, L.; Teeple, A.; Towers, G.H. The anti-HIV activity of the phytochemical alpha-terthienyl. Antiviral Res. 1993, 20, 33-43. [CrossRef]

13. Nivsarkar, M.; Kumar, G.P.; Laloraya, M. Superoxide dismutase in the anal gills of the mosquito larvae of Aedes aegypti: Its inhibition by a-terthienyl. Arch. Insect. Biochem. Physiol. 1991, 16, 249-255. [CrossRef] [PubMed]

14. Nikolas, F.; Charles, L.C.; Stephen, O.D. Antifungal activity of thiophenes from Echinops ritro. J. Agric. Food Chem. 2006, 54, 1651-1655.

15. Zhou, R.; Makabel, B.; Jia, X.G.; Si, J.Y. Studies on chemical constituents of Echinops ritro L. Acta Bot. Boreal.-Occident. Sin. 2011, 31, 616-619.

16. Liu, Y.; Ye, M.; Guo, H.Z.; Zhao, Y.Y.; Guo, D.A. New thiophenes from Echinops grijisii. J. Asian Nat. Prod. Res. 2002, 4, 175-178. [CrossRef] [PubMed]

17. Wang, Y.; Li, X.; Li, L.H.; Meng, D.L.; Li, Z.L.; Li, N. Two new thiophenes from Echinops latifolius and their phototoxic activities. Planta Med. 2007, 73, 696-698. [CrossRef] [PubMed]

18. Umeyama, A.; Nagano, C.; Arihara, $S$. Three novel $C_{21}$ polyacetylenes from the marine sponge Callyspongia sp. J. Nat. Prod. 1997, 60, 131-133. [CrossRef]

19. Zhu, H.J.; Ren, J.; Pittman, C.U., Jr. Matrix model to predict specific optical rotations of acyclic chiral molecules. Tetrahedron 2007, 63, 2292-2314. [CrossRef]

20. Zhang, L.; Shen, Y.; Zhu, H.J.; Wang, F.; Leng, Y.; Liu, J.K. Pentanol derivatives from basidiomycete Catathelasma imperiale and their 11beta-hydroxysteroid dehydrogenases inhibitory activity. J. Antibiot. 2009, 62, 239-242. [CrossRef] [PubMed]

21. Wei, H.X.; Gao, W.Y.; Guan, Y.K.; Huang, M.H.; Cheng, D.L. Study on lipophilic chemical constituents of Rhaponticum uniflorum. Lanzhou Daxue Xuebao Ziran Kexueban 1997, 33, 79-82.

22. Liang, D.; Li, N.; Xiao, W.; Zhang, P.; Ma, Z.J.; Li, X. Chemical constituents of the root of Echinops grijsii Hance. Shenyang Yaoke Daxue Xuebao 2008, 25, 620-622.

23. Schulte, K.E.; Reisch, J.; Hoerner, L. Thiophenes from alkynes, I. Chem. Berichte 1962, 95, 1943-1954. [CrossRef]

24. Maldonado, Z.; Hoeneisen, M.; Silva, M.A. Dithiophene from Aphyllocladus denticulatus. Phytochemistry 1988, 27, 2993-2994. [CrossRef]

25. Ahmad, V.U.; Alam, N.A. Acetylenic thiophene derivatives from Glumea obliqua. Phytochemistry 1996, 42, 733-735. [CrossRef] 
26. Wang, Y.; Li, X.; Meng, D.L.; Li, N.; Zhang, Y.W. Chemical constituents of thiophenes from Echinops latifolius Tausch. Shenyang Yaoke Daxue Xuebao 2008, 25, 194-196.

27. Wei, H.X.; Gao, W.Y.; Tian, Y.J.; Guan, Y.K.; Huang, M.H.; Cheng, D.L. New eudesmane sesquiterpene and thiophene derivatives from the roots of Rhaponticum uniflorum. Pharmazie 1997, 52, 245-247.

28. George, J.; Bais, H.P.; Ravishankar, G.A. Biotechnological production of plant-based insecticides. Crit. Rev. Biotechnol. 2000, 20, 49-77. [CrossRef] [PubMed]

29. DiCosmo, F.; Towers, G.H.N.; Lam, J. Photoinduced fungicidal activity elicited by naturally occurring thiophene derivatives. Pestic. Sci. 1982, 13, 589-594. [CrossRef]

30. Okanya, P.W.; Mohr, K.I.; Gerth, K.; Jansen, R.; Muller, R. Marinoquinolines A-F, pyrroloquinolines from Ohtaekwangia kribbensis (Bacteroidetes). J. Nat. Prod. 2011, 74, 603-608. [CrossRef] [PubMed]

31. Zeng, X.B.; Qiu, Q.; Jiang, C.G.; Jing, Y.T.; Qiu, G.F.; He, X.J. Antioxidant flavanes from Livistona chinensis. Fitoterapia 2011, 82, 609-614. [CrossRef] [PubMed]

32. Bohlman, F.; Suwita, A. Polyacetylenic compounds. Further constituents from species of the tribus Arctotideae. Chem. Ber. 1975, 108, 515-519.

Sample Availability: Samples of the compounds 1-16 are available from the authors. 